\title{
Managing a Hemodialysis Unit in Times of Pandemic to COVID-19. Experience of Edith Lucie Bongo Ondimba General Hospital
}

\author{
Pierre Eric Gandzali Ngabe1, Hamadoun Yattara², Djibrilla Bonkano Baoua3, \\ Richard Loumingou', Donatien Moukassa ${ }^{1}$
}

${ }^{1}$ Edith Lucie Bongo Ondimba Hospital General, Oyo, Congo

${ }^{2}$ Teaching Hospital of POINT G Bamako, Bamako, Mali

${ }^{3}$ Aristide Le Dantec Hospital, Dakar, Senegal

${ }^{4}$ Teaching Hospital of Brazzaville, Brazzaville, Congo

Email: ngabe_eric@yahoo.fr

How to cite this paper: Ngabe, P.E.G., Yattara, H., Baoua, D.B., Loumingou, R. and Moukassa, D. (2020) Managing a Hemodialysis Unit in Times of Pandemic to COVID-19. Experience of Edith Lucie Bongo Ondimba General Hospital. Open Journal of Nephrology, 10, 223-226.

https://doi.org/10.4236/ojneph.2020.103021

Received: May 11, 2020

Accepted: July 10, 2020

Published: July 13, 2020

Copyright $\odot 2020$ by author(s) and Scientific Research Publishing Inc. This work is licensed under the Creative Commons Attribution International License (CC BY 4.0).

http://creativecommons.org/licenses/by/4.0/

\begin{abstract}
This is the description of the prevention and the development of the sessions of hemodialysis in our center hemodialysis to not be contaminated coronavirus. Actions taking are: respect of the measures decreed by the state for prevention. Although these measures are difficult socio-cultural for Africans, they became normal after two weeks. The hemodialysis is made free during this period in our public center. Indeed, the session of hemodialysis was 10,000 francs Africans financial community (CFA in french) or 16.72 American dollar, from the declaration of the state of emergency it has become free. We do hemodialysis free and explanation of covid19 signs in hemodialysis patients systematically. Each patient had the explanation of the pathology and above all we did everything to de-stress the patients, because there is a global psychosis. Cleaning hand before entering the hemodialysis room, we have positioned front of the hospital and before the service and the front of room hemodialysis, seals for washing hands. We monitor the temperature before hemodialysis with a thermoflash or a mercury thermometer for each patient. We made a mandatory to wear masks for all patients during hemodialysis sessions. We shared the masks in loincloth with liners to all the patients a local manufacture.
\end{abstract}

\section{Keywords}

Management, Hemodialysis Cost, COVID-19, Congo, Brazzaville 


\section{Introduction}

This is the description of the prevention and the development of the sessions of hemodialysis in our center hemodialysis to not be contaminated coronavirus.

The new coronavirus disease is a contagious disease caused by SARS-CoV2. This is a virus RNA of Betacoronavirus family. The new Coronavirus has been identified in humans, but similar with other coronaviruses in bats. The species SARS related coronavirus and receiver is enzyme conversion of angiotensin 2.

The diagnosis is based on the history of contact. The COVID-19 manifests as fever (98\%), dry cough (76\%), myalgia and asthenia (18\% each) [1] [2] [3]. The COVID-19 should not be allowed to overlook other serious pathologies of differential diagnosis, such as malaria, tuberculosis and heart disease. The incubation time can range from 2 days to 30 days depending on the patient, but often 2 to 14 days [4]. The aspects radiation are: grounds glass (65\%), of unilateral approach (60\% in pre-clinical phase), predominantly in the lower right lobe, bilatéralisation (90\%) and diffuse (52\%) during the first week of evolution. These severe cases include: images of condensation (30\%); the cross-linked images (33\%); the pleural effusion (13\%) and mediastinal lymphadenopathy (13\%). The renal involvement is manifested by proteinuria in $44 \%$; hematuria in $26.4 \%$ and the creatinine level is high in $15.5 \%$ [5].

The pathogenesis of the coronavirus can be explained by the binding of $S$ protein with the respiratory syncytial cells, the replicating RNA fusion viral and $\mathrm{N}$ glycosylation of S protein. The physiopathology of COVID-19 is explained by the blocking of ECA 2 (vasodilatation), an increase in TNF (fever) and dry cough and diarrhea due to the increase in bradykinin [6] [7].

\section{Discussion}

The current treatment applied in Congo Brazzaville by the national guide taking care of COVID-19 last update in April 2020 was; A combination therapy:

- Hydroxychloroquine $200 \mathrm{mg} ; 200 \mathrm{mg} \times 2$ /day for $7-10$ days. Side effects: risk of hemolysis; QT lengthening.

- Azithromycin $500 \mathrm{mg} ; 500 \mathrm{mg}$ by day and $250 \mathrm{mg}$ by day to day ten. Side effects: QT prolongation; neuro hepato and haemato toxicity.

- HAART: Lopinavir + ritonavir $(200 \mathrm{mg} / 50 \mathrm{mg}): 2$ tablets $\times 2 /$ day for 10 to 20 days. Side effects: formation of urinary calculus.

Either Remdesivir $200 \mathrm{mg} ; 200 \mathrm{mg}$ first day then $100 \mathrm{mg}$ by day for 5 to 10 days. Side effects: formation of urinary calculus [8] [9]. We give the same treatment like Marseille in France [10].

The follow Table 1 describe the moment for ware a different protective equipment.

The actions taken:

1) Respect of the measures decreed by the state for prevention. Although these measures are difficult socio-cultural for us Africans but they became normal after two weeks. 
Table 1. Suggestion on the protective equipment required for different levels of contact.

\begin{tabular}{|c|c|c|c|c|c|c|}
\hline Interaction level & $\begin{array}{c}\text { Hand } \\
\text { hygiene }\end{array}$ & Blouse & $\begin{array}{l}\text { Medical } \\
\text { mask }\end{array}$ & $\begin{array}{c}\text { Respirator } \\
\text { (N95 or FFP2) }\end{array}$ & $\begin{array}{c}\text { Glasses } \\
\text { (eye protection) } \\
\text { or face shield }\end{array}$ & Gloves \\
\hline Sorting & $\mathrm{X}$ & & $\mathrm{X}$ & & & \\
\hline $\begin{array}{l}\text { Collection of } \\
\text { laboratory samples }\end{array}$ & $\mathrm{X}$ & $\mathrm{X}$ & & $\mathrm{X}$ & $\mathrm{X}$ & $\mathrm{X}$ \\
\hline $\begin{array}{l}\text { Management of suspected } \\
\text { or confirmed COVID-19 } \\
\text { cases without performing } \\
\text { the procedures that } \\
\text { generate the aerosols }\end{array}$ & $\mathrm{X}$ & $\mathrm{X}$ & $\mathrm{X}$ & & $\mathrm{X}$ & $\mathrm{X}$ \\
\hline $\begin{array}{l}\text { Management of suspected } \\
\text { or confirmed cases of } \\
\text { COVID-19 by performing } \\
\text { the procedures that } \\
\text { generate aerosols }\end{array}$ & $\mathrm{X}$ & $\mathrm{X}$ & & $\mathrm{X}$ & $\mathrm{X}$ & $\mathrm{X}$ \\
\hline
\end{tabular}

2) The hemodialysis is made free during this period in our public center. Indeed the cost of hemodialysis session was 10,000 francs Africans financial community (CFA in french) or 1672 American dollar from the declaration of the state of emergency it has become free. The only free center is in central Africa.

3) Explanation of the signs of COVID-19 to hemodialysis patients. Each patient had the explanation of the pathology and above all we did everything to de-stress the patients because there is a global psychosis.

4) Hand cleaning before entering the hemodialysis room. We have positioned that in the hospital before the service and the front of room of hemodialysis seals for washing hands.

Monitoring temperature before connection to hemodialysis with the thermoflash or a mercury thermometer for each patient [9].

5) Obligation to wear masks for all patients during hemodialysis sessions. We gave the masks in loincloth with liners to all the patients from a local manufacture.

Systematically two sessions for all patients except patients require more and unstable to balance them. We did the same actions like France [10].

\section{Conclusion}

These measures allow kidneys failure patients to continue their hemodialysis care despite confinement, lack of financial means and quickly stop the spread of the disease. No patient with kidney failure has COVID-19. Epidemiological surveillance remains on alert.

\section{Conflicts of Interest}

The authors declare no conflicts of interest regarding the publication of this paper. 


\section{References}

[1] Wang, D., Hu, B., Hu, C., Zhu, F., Liu, X., Zhang, J., Wang, B., et al. (2020) Clinical Characterics of 138 Patients with 2019 Novel Coronavirus-Infected Pneumonia in Wuhan, China. JAMA, 323, 1061-1069. https://doi.org/10.1001/jama.2020.1585

[2] Guan, W., Ni, Z., Hu, Y., Liang, W., Ou, C., He, J., et al. (2020) Clinical Characteristics of Coronavirus Disease 2019 in China. The New England Journal of Medicine, 382, 1708-1720. https://doi.org/10.1056/NEJMoa2002032

[3] Huang, C., Wang, Y., Li, X., et al. (2020) Clinical Features of Patients Infected with 2019 Novel Coronavirus in Wuhan, China. Lancet, 20, 30183-30185. https://doi.org/10.1016/S0140-6736(20)30183-5

[4] Chen, N., Zhou, M., Dong, X., et al. (2020) Epidemiological and Clinical Characteristics of 99 Cases of 2019 Novel Coronavirus Pneumonia in Wuhan, China: A Descriptive Study. Lancet, 395, 507-513. https://doi.org/10.1016/S0140-6736(20)30211-7

[5] Shi, H., Han, X., Jiang, N., et al. (2020) Radiological Findings from 81 Patients with COVID-19 Pneumonia in Wuhan, China: A Descriptive Study. The Lancet Infectious Diseases, 20, 425-434. https://doi.org/10.1016/S1473-3099(20)30086-4

[6] Lan, L., Xu, D., Ye, G., Xia, C., Wang, S., Li, Y., et al. (2020) Positive RT-PCR Test Result in Patients Recovered from COVID-19. JAMA, 323, 1502-1503. https://doi.org/10.1001/jama.2020.2783

[7] Lai, C.C., Shih, T.P., Ko, W.C., Tang, H.J. and Hsueh, P.R. (2020) Severe Acute Respiratory Syndrome Coronavirus 2 (SARS-CoV-2) and Coronavirus Disease-2019 (COVID-19): The Epidemic and the Challenges. International Journal of Antimicrobial Agents, 55, Article ID: 105924.

https://doi.org/10.1016/j.ijantimicag.2020.105924

[8] National Guide to the Management of Cases of COVID-19. Republic of the Congo.

[9] Naicker, S., Yang, C., Wang, S.H., Liu, B., Chen, J. and Jha, V. (2020) The Novel Coronavirus 2019 Epidemic and Kidneys. Kidney International, 97, 824-828. https://doi.org/10.1016/j.kint.2020.03.001

[10] Gautret, P., Lagier, J.-C., Parola, P., Thuan Hoang, V., Meddeb, L., Sevestre, J., et al. (2020) Clinical and Microbiological Effect of a Combination of Hydroxychloroquine and Azithromycin in 80 COVID-19 Patients with at Least a Six-Day Follow Up: A Pilot Observational Study. Travel Medicine and Infectious Disease, 34, Article ID: 101663. https://doi.org/10.1016/j.tmaid.2020.101663 